\title{
HOW DOES ECONOMIC EMPOWERMENT AFFECT WOMEN'S RISK OF INTIMATE PARTNER VIOLENCE IN LOW AND MIDDLE INCOME COUNTRIES? A SYSTEMATIC REVIEW OF PUBLISHED EVIDENCE ${ }^{\dagger}$
}

\author{
SEEMA VYAS* and CHARLOTTE WATTS \\ London School of Hygiene and Tropical Medicine, London, UK
}

\begin{abstract}
Objectives: To identify whether individual and household economic empowerment is associated with lower intimate partner violence in low and middle income country settings. Methods: Systematic PubMed and internet searches. Results: Published data from 41 sites were reviewed. Household assets and women's higher education were generally protective. Evidence about women's involvement in income generation and experience of past year violence was mixed, with five finding a protective association and six documenting a risk association. Conclusion: At an individual and household level, economic development and poverty reduction may have protective impacts on IPV. Context specific factors influence whether financial autonomy is protective or associated with increased risk. Copyright (C) 2008 John Wiley \& Sons, Ltd.
\end{abstract}

Keywords: intimate partner violence; poverty; education; women's empowerment; micro-credit; women's employment; low and middle income countries

\section{INTRODUCTION}

Globally, gender-based violence is increasingly recognised as an important social, health and human rights problem crossing regional, social and cultural boundaries (Krug et al., 2002; WHO, 2005). Violence by an intimate partner is one of the most common forms of gender-based violence, with population surveys suggesting that between 15 and 71 per cent of ever partnered women globally have been physically or sexually assaulted by an intimate partner at sometime in their lives (Garcia-Moreno et al., 2006).

*Correspondence to: Seema Vyas, London School of Hygiene and Tropical Medicine, Health Policy Unit, 36 Gordon Square, London WC1H 0PD, UK. E-mail: seema.vyas@1shtm.ac.uk

${ }^{\dagger}$ This article was published online on 6 October 2008. Errors were subsequently identified. This notice is included in the online and print versions to indicate that both have been corrected [17 April 2009]. 
Intimate partner violence (IPV) has been shown to adversely affect women's health, with evidence of an increased risk of HIV/AIDS, peri-natal and neonatal mortality, and a range of reproductive, mental and physical health outcomes (Jejeebhoy, 1998; Campbell, 2002; Ahmed et al., 2006; Dunkle et al., 2006). Violence has also been shown to limit the degree to which women are able to work, earn an income or independently make decisions about their health and their children's schooling and use of health services (Krug et al., 2002; Gibson-Davis et al., 2005), and so is an important barrier to development.

Within the development literature, the economic and social empowerment of women is recognised as a central strategy to help address poverty, and many development strategies target poor women (WHO, 2005). The rationale for women's economic and social empowerment is well established, with evidence from a range of settings finding that when given access to financial resources, women are more likely to invest in their children's education and nutrition (Quisumbing and Maluccio, 2003; Kabeer and Mahmud, 2004; Roushdy, 2004), have improved health seeking behaviour, and improved antenatal attendance and reduced fertility (Schultz, 1990; Kadir et al., 2003).

Theoretically also, the economic empowerment of women has the potential to have a positive or negative impact on women's risk of violence. Women with education or who contribute financially may have a higher status in their household, and be less vulnerable to abuse. Conversely, this may challenge the established status quo and power balance with her partner, and so be associated with an increased risk of violence. Given the important benefits of economic empowerment, it is important to understand the relationship between economic empowerment and women's risk of violence in different settings.

After a discussion of the theoretical models of the relationship between economic empowerment and IPV, this paper presents a review of existing published evidence on the relationship between different forms of economic empowerment and women's risk of IPV. The implications for social and development policy are then discussed.

\subsection{Theoretical Models of the Relationship Between Economic Empowerment and Risk of IPV}

An evolving body of economic and sociological theories have sought to explain how women's risk of IPV may be affected by the absolute and relative level of resources within a household, with different theories having different conclusions about the way in which women's economic empowerment may affect women's risk of IPV.

Framed around the sociological perspective of social exchange theory, where social interactions are governed when the benefits of the interaction outweigh the costs, resource theory asserts that the family is a power system and that men with few economic resources (earnings, social status, education attainment) may use violence as an alternative form of resource to control their partner. This theory sees violence as an additional resource that men can use to maintain dominance within the family, and that there will be a correlation between poverty and IPV (Goode, 1971).

This has been expanded to more explicitly to consider the relative distribution and differentials in resources (Relative resource theory) (McCloskey, 1996; Macmillan and Gartner, 1999). This theory suggests that where status inconsistency exists (i.e. women who are employed when their partner is not, have a higher income than their partner, or have more education than their partner), women with higher status are at an increased risk of violence, because they are challenging men's status as head of the household. However, such assumptions have been critiqued by gendered resource theorists. They highlight that this 
ignores cultural variables and gender ideologies, with relative resource theory assuming that all men want to be the main income earner and dominate decision making. They further propose that women's higher status will not be associated with an increased risk of violence if the partner holds more egalitarian views on gender ideologies (Atkinson and Greenstein, 2005).

In contrast, marital dependency theory argue that women who are economically dependent on their partner are at greater risk of IPV (Dobash and Dobash, 1979; Kalmuss and Straus, 1982; Hornung et al., 1981; Gelles, 1976). They argue that women with few economic resources cannot easily leave their partner, and are less able to negotiate change, leading to higher endurance for IPV. Economists have used household models to understand women's risk of IPV, and propose that increasing women's economic resources empowers her to bargain for a better situation for herself or to leave, therefore, reducing her risk of abuse (Tauchen et al., 1991; Tauchen and Witte, 1995; Holvoet, 2005).

In addition, the ecological model proposes that the factors associated with IPV is multifaceted, and that it is an interplay of individual, family and community factors that influences the likelihood of whether violence may occur within a household or not (Heise, 1998). Within this framework, the absolute or relative levels of education or employment that women and men have within a partnership are recognised as being potentially influential, but the role of other contextual factors is also more explicitly acknowledged.

\section{METHODS}

The search strategy aimed to identify papers that presented empirical population-based quantitative findings about the association between different indicators of women's economic and social empowerment and women's reported experience of IPV in low and middle income countries (LMICs, as defined by the World Bank classifications ${ }^{1}$ ). As it was recognised that women's risk of violence would be strongly influenced by a woman's age (with younger women being at greater risk of ongoing violence, and older women potentially having greater risk of ever having experienced violence), our review only included findings from multivariate analyses that had controlled for age-related variables (age of woman or length/duration of relationship; age at union). Also included in the review were the results from intervention studies that sought to economically or socially empower women.

Between January and August 2007 a PubMed search was conducted using the terms [partner violence; IPV; spouse abuse; wife abuse, domestic violence AND survey; domestic violence AND low income; domestic violence AND middle income; domestic violence AND developing country]. In total almost 9000 (8969) articles were identified. Articles (8194) remained after duplicates and articles with either no author or that were not in English were rejected. Based on titles and abstracts, the vast majority of articles were rejected because they had an industrial country focus; were not population based (e.g. clinic); focussed on childhood, elderly or same-sex couple abuse or did not report risk or protective factors associated with violence.

Sixty-three articles were then reviewed in full (note one article could not be obtained but we contacted the author who sent us the masters thesis the article was based on). Ten articles either analysed data using a sample of men (nine) or a combined men and women sample (one). Of the remaining 53 articles a further 24 were excluded: twelve presented bivariate analyses only; seven reported IPV prevalence but not associated risk and protective

\footnotetext{
${ }^{1}$ http://web.worldbank.org/WBSITE/EXTERNAL/DATASTATISTICS/0,,contentMDK:20421402 $\sim$ pagePK:64133150 piPK:64133175 theSitePK:239419,00.html accessed on 29th August 2007.
} 
factors; three were clinic based; one was a review article and another presented qualitative research. Of the remaining 29 articles five used the same data reporting the same findings. Therefore, 24 articles were included from the PubMed search.

A further three studies were identified from a grey literature search on the internet, and three additional articles were identified from the reference lists from journals/articles not picked up from the database search. In total, this gave 30 studies included for this review, with four presenting intervention data.

Data extracted included country/location of study, year of data collection, characteristics of sampled women, measure of violence and prevalence of violence (ever and past year). Evidence presented on the association between different indicators of women's empowerment and women's ever and past year experience of IPV were both summarised.

\section{RESULTS}

Thirty articles were included in the study, analysing data from LMICs and yielding results from 41 sites (Table 1). ${ }^{2}$ Most studies analysed population-based cross-sectional data from 40 sites, and one analysed the impact of an empowerment interventions on women's risk of violence (South Africa). The study years (data collection) ranged from 1992 (Schuler et al., 1996; Oropesa, 1997) to 2005 (Aekplakorn and Kongsakon, 2007). Data had been collected before 2000 in 17 sites and from 2000 in 24. Most (38) specified the age of the woman sampled, with the most common age range being 15-49 (23 sites). Thirty-six sites specified the status of the women sampled, with 16 being ever married or ever partnered women, and 17 currently married or partnered women. Of the remaining three the sampling criteria were women who were sexually active, women with a child less than one year of age and women representing the family. Fifteen sites asked a number of questions about specific acts of violence based on established tools and questionnaires, for example the Conflict Tactics Scale (CTS), and in another 15 sites one broad question was asked about physical violence (most commonly whether the woman had been beaten, others were whether the woman had been hit, assaulted mistreated or hurt). Of these, in three sites an additional question on whether the respondent had experienced sexual violence was asked. In a further eight sites, either three or four questions were asked. One study in Turkey (Kocacik and Dogan, 2006) reported prevalence of physical violence, but did not specify how violence was measured, one study asked about experience of physical and or sexual violence (Pronyk et al., 2006) and one study asked about sexual violence only (Brown et al., 2006). ${ }^{3}$

Twenty-two sites documented ever physical violence, and prevalence ranged between 13 and 67 per cent. Ever physical/sexual violence was documented in eight sites (prevalence range of 17.5-54.3 per cent (includes threat)), past year physical violence was documented in 24 sites (prevalence range of 7.2-46.8 per cent) and past year physical/ sexual violence in 10 sites (prevalence range of 11.0-30.9 per cent (includes threat)). The intervention study measured the levels of violence among intervention recipients. Five sites recorded ever experience of sexual violence (prevalence range of 3.4-37 per cent) and four

\footnotetext{
${ }^{2}$ India urban and rural combined in multivariate analysis (Panda and Agarwal).

${ }^{3}$ Separate acts of violence were considered in the following groups:

Threat: threaten with violence/to kill; threaten to hurt family/friends; use threatening gestures; use insults sworn. Physical: kick, drag, pull, held down; push, shake; slap; burnt, scalded; beaten, hurt; punch, hit with fists, hit; hit with weapon, blow with an object; threw object; bitten; choke, strangled; threaten with a weapon; other for example locked up.

Sexual: forced to have sex; had sex when did not want to.
} 


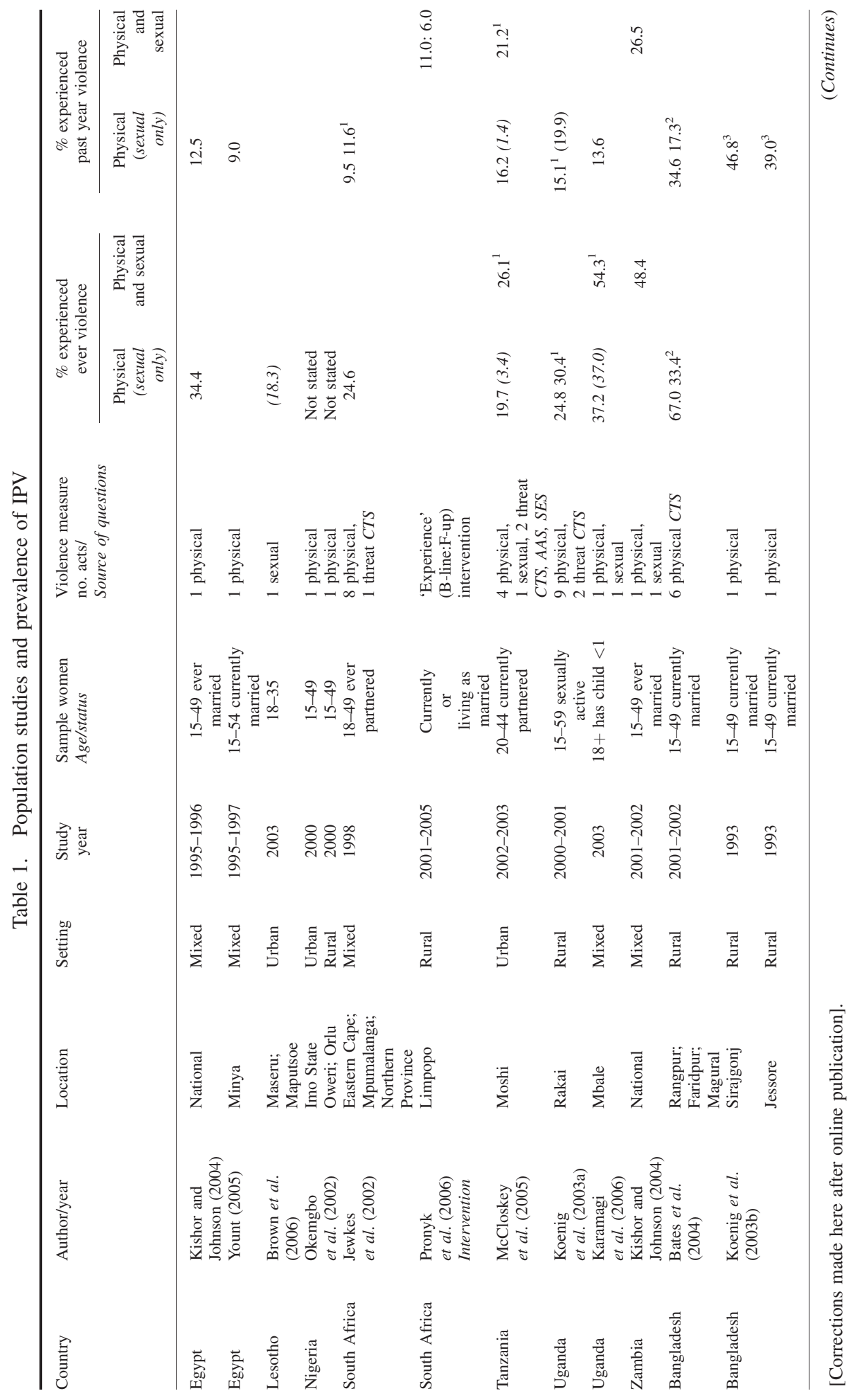




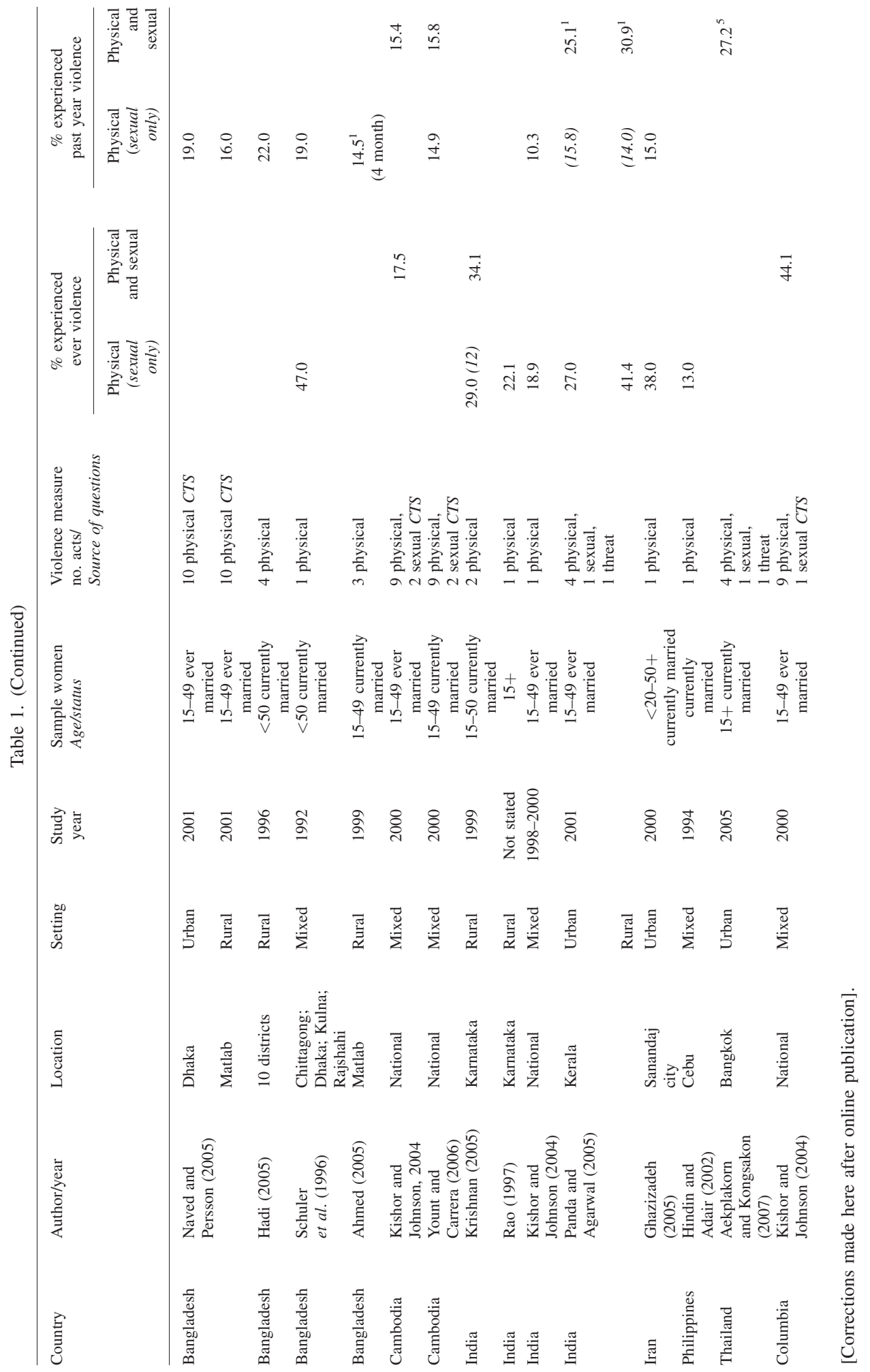


$\stackrel{\circ}{=}$ $\stackrel{\sim}{3}$

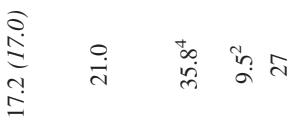

$\stackrel{\circ}{\stackrel{m}{m}}$

$\stackrel{2}{2}$

$\stackrel{\text { ลี }}{3}$

ঙี่

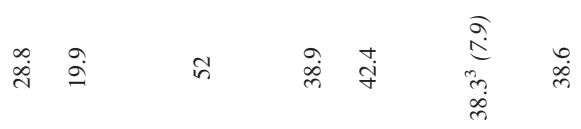

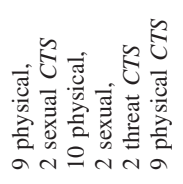

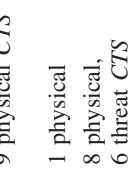

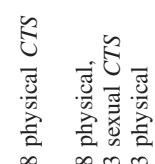

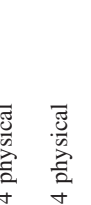

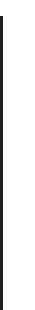

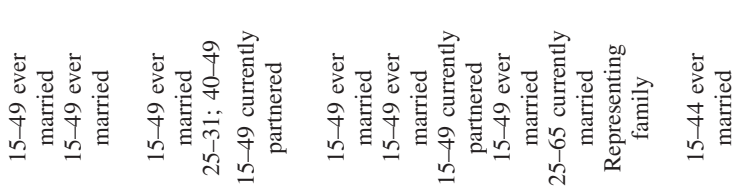

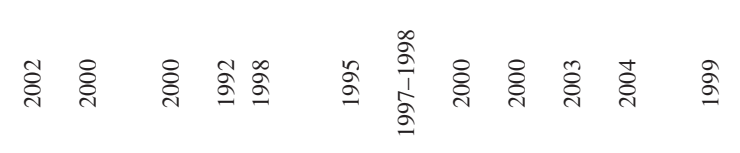

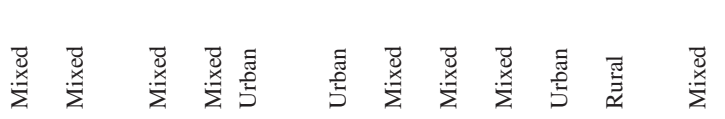

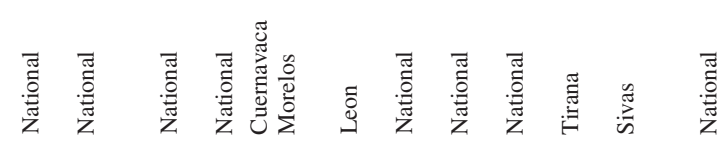

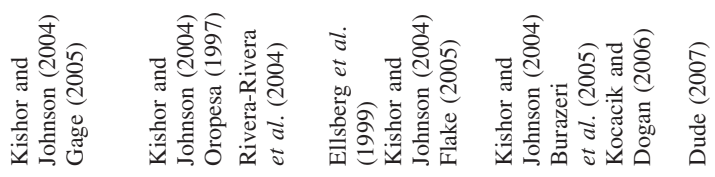

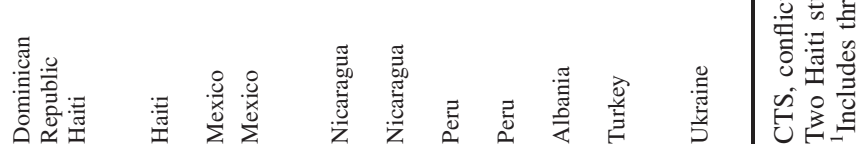


sites recorded past year experience of sexual violence (prevalence range of 1.4-17 per cent). One study investigated correlates with IPV in two Nigeria sites but did not provide data on the prevalence of violence.

The most common measure of poverty used was based on ownership of assets (23) either classified into socioeconomic categories or developed into a scale, land ownership was used in three sites and housing characteristics in one site. Nine sites used monetary measures of poverty either household income (six) or expenditure (two) and one site used both (note in two separate models). The remaining two sites used a self-perceived poverty status measure, or a measure based on access to basic needs. Two measures of education attainment were commonly used, level of achievement (e.g. none, primary, secondary or more) and years in school (generally 5 or more years). Higher education was compared in three sites (e.g. education beyond the age of 16 or university), two compared some schooling with no schooling (we assume primary with none) and one compared high education with low education. Relative education mostly compared more women's education with equal or less than men's education. Economic empowerment was defined as women's access to resources either through income generating activities (employment or credit programmes). Additional measures of economic empowerment included a woman's ownership of land or property, control over her resources or decision-making power (autonomy) or her contribution to the household expenses.

\subsection{Violence and Poverty}

The relationship between violence and poverty was examined in 34 of the 41 sites (Table 2). Fifteen sites investigated the association between ever violence and asset wealth, with a significant protective association being found in five settings, including a significant decreasing trend association in India, the Philippines and Ukraine (Hindin and Adair, 2002; Kishor and Johnson, 2004; Dude, 2007). When compared to the poorest socioeconomic group, the highest asset quintile was associated with significantly lower physical violence in Egypt and in Peru (Kishor and Johnson, 2004). In three sites (Zambia, Cambodia and Columbia), the association between socioeconomic status (SES) and physical/sexual violence was not trended (Kishor and Johnson, 2004). The other seven studies showed no significant association. A further five sites investigated whether physical violence was associated with monetary measures of household SES. Higher income was associated with significantly higher physical violence in two Nigerian sites (Okemgbo et al., 2002). Higher household income and monthly expenditure was slightly but significantly associated with lower physical violence in India (Rao, 1997; Panda and Agarwal, 2005) and in Turkey income was significantly associated with physical violence but it is not clear in which direction as the comparison group was not stated (Kocacik and Dogan, 2006).

Sixteen sites investigated the association between past year violence and asset wealth. There was a significant decreasing association in three Bangladesh sites, Egypt and Ukraine (Koenig et al., 2003b; Bates et al., 2004; Yount, 2005; Dude, 2007) and a decreasing trend by socioeconomic group in India, Egypt and Cambodia (Kishor and Johnson, 2004; Yount and Carrera, 2006). Severe physical violence was significantly lower in high SES households compared with low SES in Mexico though there was no significant association between moderate physical violence and SES (Rivera-Rivera et al., 2004). There were significant protective relationships between asset wealth and physical and/or sexual violence in Zambia and Cambodia (Kishor and Johnson, 2004) though a trend was not clear, and no significant association in the other five sites. Of the seven sites using non- 
Table 2. Association between IPV and household socioeconomic status and income

\begin{tabular}{|c|c|c|c|c|}
\hline Study & $\begin{array}{l}\text { Violence } \\
\text { measure }\end{array}$ & $\begin{array}{l}\text { SES level compared } \\
\text { Reference group }\end{array}$ & $\begin{array}{l}\text { Ever violence } \\
\text { odds ratio }(\mathrm{CI})\end{array}$ & $\begin{array}{l}\text { Past year violence } \\
\text { odds ratio }(\mathrm{CI})\end{array}$ \\
\hline Egypt & Physical & Asset quintiles & & \\
\hline Kishor and & & 1 poor, 2 & 1.07 & 0.93 \\
\hline \multirow{3}{*}{ Johnson (2004) } & & 3 & 0.88 & $0.70^{* * *}$ \\
\hline & & 4 & $0.71^{*}$ & $0.58^{* *}$ \\
\hline & & 5 & $0.51^{* *}$ & $0.41^{* *}$ \\
\hline Egypt & Physical & Asset wealth & & $0.83^{*}$ \\
\hline Yount (2005) & & index & & \\
\hline Lesotho & Sexual & Mean number & $0.95(0.83-1.08)$ & \\
\hline Brown et al. (2006) & & of assets & & \\
\hline Uganda & Physical/sexual/ & Asset quintiles & Data not & \\
\hline Karamagi et al. (2006) & threat & $\begin{array}{l}1-3 \text { poor } \\
4-5 \text { least poor }\end{array}$ & shown NS & \\
\hline Zambia & Physical/sexual & Asset quintiles & & \\
\hline \multirow[t]{4}{*}{ Kishor and Johnson (2004) } & & 1 poor, 2 & $0.77^{*}$ & $0.76^{*}$ \\
\hline & & 3 & 0.90 & 0.83 \\
\hline & & 4 & 0.93 & $0.69^{*}$ \\
\hline & & 5 & 1.11 & 0.97 \\
\hline Bangladesh & Physical & Asset scale (0-7) & & $0.81^{* * *}(0.73-0.89)$ \\
\hline \multicolumn{5}{|l|}{ Bates et al. (2004) } \\
\hline Bangladesh & Physical & No land ownership, & & \\
\hline Sirajgonj & & land ownership & & $0.93^{* * *}$ \\
\hline Bangladesh Jessore & Physical & No land ownership, & & \\
\hline Koenig et al. (2003b) & & land ownership & & $0.94^{* * *}$ \\
\hline Bangladesh & Physical & Housing material & & \\
\hline Schuler et al. (1996) & & poor, less poor & & $0.89(0.64-1.23)$ \\
\hline Cambodia & Physical/sexual & Asset quintiles & & \\
\hline \multirow[t]{4}{*}{ Kishor and Johnson (2004) } & & 1 poor, 2 & 0.85 & 0.84 \\
\hline & & 3 & $0.66^{* *}$ & $0.57^{*}$ \\
\hline & & 4 & 0.76 & 0.85 \\
\hline & & 5 & 0.77 & 0.82 \\
\hline Cambodia & Physical & Asset quartiles & & \\
\hline \multirow[t]{2}{*}{ Yount (2006) } & & 1 poor, 2nd quartile & & $0.79(0.57-1.09)$ \\
\hline & & Upper $50 \%$ & & $0.55^{* * *}(0.39-0.76)$ \\
\hline India & Physical & Asset quintiles & & \\
\hline \multirow[t]{4}{*}{ Kishor and Johnson (2004) } & & 1 poor, 2 & $0.87^{* *}$ & $0.86^{* *}$ \\
\hline & & 3 & $0.72^{* *}$ & $0.68^{* *}$ \\
\hline & & 4 & $0.54^{* *}$ & $0.49^{* *}$ \\
\hline & & 5 & $0.30^{* *}$ & $0.26^{* *}$ \\
\hline India & Physical & No land ownership, & & \\
\hline \multirow[t]{2}{*}{ Krishnan (2005) } & & land ownership & $0.79(0.50-1.23)$ & \\
\hline & & $\begin{array}{l}\text { No TV ownership, } \\
\text { TV ownership }\end{array}$ & $0.78(0.34-1.80)$ & \\
\hline Columbia & Physical/sexual & Asset quintiles & $0.10(0.07-1.00)$ & \\
\hline \multirow[t]{4}{*}{ Kishor and Johnson (2004) } & & 1 poor, 2 & 1.16 & \\
\hline & & 3 & $1.43^{* *}$ & \\
\hline & & 4 & 1.21 & \\
\hline & & 5 & 1.08 & \\
\hline Dominican Republic & Physical/sexual & Asset quintiles & & \\
\hline \multirow[t]{4}{*}{ Kishor and Johnson (2004) } & & 1 poor, 2 & 0.96 & 0.93 \\
\hline & & 3 & 0.93 & 0.88 \\
\hline & & 4 & 0.83 & 0.84 \\
\hline & & 5 & 0.72 & 0.86 \\
\hline Mexico & Physical low/ & Assets low, medium & & $0.99(0.72-1.36)$ \\
\hline \multirow[t]{3}{*}{ Rivera-Rivera et al. (2004) } & moderate & high + & & $0.83(0.62-1.10)$ \\
\hline & Physical severe & Assets low, medium & & $1.09(0.65-1.83)$ \\
\hline & & high + & & $0.57(0.34-0.95)$ \\
\hline
\end{tabular}

[Corrections made here after online publication].

(Continues) 
Table 2. (Continued)

\begin{tabular}{|c|c|c|c|c|}
\hline Study & $\begin{array}{l}\text { Violence } \\
\text { measure }\end{array}$ & $\begin{array}{l}\text { SES level compared } \\
\text { Reference group }\end{array}$ & $\begin{array}{l}\text { Ever violence } \\
\text { odds ratio }(\mathrm{CI})\end{array}$ & $\begin{array}{l}\text { Past year violence } \\
\text { odds ratio }(\mathrm{CI})\end{array}$ \\
\hline Nicaragua & Physical/sexual & Asset quintiles & & \\
\hline \multirow[t]{4}{*}{ Kishor and Johnson (2004) } & & 1 poor, 2 & 1.05 & 0.89 \\
\hline & & 3 & 1.03 & 0.95 \\
\hline & & 4 & 1.02 & 1.13 \\
\hline & & 5 & 0.89 & 0.85 \\
\hline \multirow{6}{*}{$\begin{array}{l}\text { Peru } \\
\text { Flake (2005) } \\
\text { Peru } \\
\text { Kishor and Johnson (2004) }\end{array}$} & Physical & Asset scale (0-7) & 1.01 & \\
\hline & Physical & Asset quintiles & & \\
\hline & & 1 poor, 2 & 1.08 & \\
\hline & & 3 & 1.06 & \\
\hline & & 4 & 0.87 & \\
\hline & & 5 & $0.63^{* *}$ & \\
\hline \multirow{2}{*}{$\begin{array}{l}\text { Philippines } \\
\text { Hindin and Adair (2002) } \\
\text { Haiti }\end{array}$} & Physical & $\begin{array}{l}\text { Number of } \\
\text { assets owned }\end{array}$ & $0.91^{*}$ & \\
\hline & Physical & Assets non-poor, poor & & 0.96 \\
\hline \multirow[t]{2}{*}{ Gage (2005) } & Sexual & Assets non-poor, poor & & 0.88 \\
\hline & Emotional & Assets non-poor, poor & & 0.87 \\
\hline Haiti & Physical & Asset quintiles & & \\
\hline \multirow[t]{4}{*}{ Kishor and Johnson (2004) } & & 1 poor, 2 & 1.12 & 1.14 \\
\hline & & 3 & 1.19 & 1.20 \\
\hline & & 4 & 0.82 & 0.81 \\
\hline & & 5 & 0.86 & 0.80 \\
\hline Ukraine & Physical & Asset index score & $0.78^{* * *}$ & $0.75^{*}$ \\
\hline \multicolumn{5}{|l|}{ Dude (2007) } \\
\hline \multirow{5}{*}{$\begin{array}{l}\text { Bangladesh } \\
\text { Ahmed (2005) } \\
\text { Nicaragua } \\
\text { Ellsberg } \text { et al. (1999) }\end{array}$} & Physical p4m & Self-rated poverty status & & \multirow{5}{*}{$1.38^{\ddagger}(1.05-1.82)$} \\
\hline & \multirow{4}{*}{ Physical } & non-deficit, deficit & & \\
\hline & & Access basic needs & & \\
\hline & & & & \\
\hline & & all three non-poor, poor & & \\
\hline Nigeria urban & Physical & $\begin{array}{l}\text { Low income, high } \\
\text { income }\end{array}$ & $1.11^{*}$ & \\
\hline \multirow{5}{*}{$\begin{array}{l}\text { Nigeria rural } \\
\text { Okemgbo et al. (2002) } \\
\text { Bangladesh urban } \\
\text { Naved and Persson (2005) }\end{array}$} & Physical & $\begin{array}{l}\text { Low income, high } \\
\text { income }\end{array}$ & $1.10^{*}$ & \\
\hline & Physical & Income quartile & & \\
\hline & & 1 poor, 2 & & 0.90 \\
\hline & & 3 & & 0.72 \\
\hline & & 4 & & 0.64 \\
\hline \multirow{4}{*}{$\begin{array}{l}\text { Bangladesh rural } \\
\text { Naved and Persson (2005) }\end{array}$} & Physical & Income quartile & & \\
\hline & & 1 poor, 2 & & 0.69 \\
\hline & & 3 & & 1.13 \\
\hline & & 4 & & 0.75 \\
\hline \multirow{3}{*}{$\begin{array}{l}\text { Bangladesh } \\
\text { Hadi (2005) } \\
\text { India (model 1) }\end{array}$} & Physical & Household expenditure & & \multirow{7}{*}{0.63} \\
\hline & & poor, non-poor & & \\
\hline & Physical & $\begin{array}{l}\text { Household monthly } \\
\text { expenditure }\end{array}$ & $1.00^{* * *}$ & \\
\hline \multirow{5}{*}{$\begin{array}{l}\text { India (model 2) } \\
\text { Rao (1997) } \\
\text { India } \\
\text { Panda and Agarwal (2005) }\end{array}$} & Physical & $\begin{array}{l}\text { Household monthly } \\
\text { income }\end{array}$ & $1.00^{* * *}$ & \\
\hline & Physical & Per capita expenditure & & \\
\hline & & $<6000,6000-11999$ & $0.09^{*}$ & \\
\hline & & $12000 \&$ above & $0.10^{*}$ & \\
\hline & $\begin{array}{l}\text { Physical/sexual/ } \\
\text { threat }\end{array}$ & $\begin{array}{l}<6000,6000-11999 \\
12000 \& \text { above }\end{array}$ & & $\begin{array}{l}0.17^{*} \\
0.15^{*}\end{array}$ \\
\hline $\begin{array}{l}\text { Albania } \\
\text { Burazeri et al. (2005) }\end{array}$ & Physical & $\begin{array}{l}\text { Household } \\
\text { monthly income } \\
\text { Low }<80 ; \text { mid } 150 ; \mathrm{h}+\end{array}$ & & \multirow[t]{3}{*}{$\begin{array}{c}\text { Data not } \\
\text { shown NS }\end{array}$} \\
\hline Turkey & Physical & (Not stated) & & \\
\hline Kocacik and Dogan (2006) & & 5000-9999 USD & $7.47(2.74-20.38)$ & \\
\hline
\end{tabular}

+ , significant trend relationship; $*<0.01 ; * * p<0.005 ; * * *<0.001 ;{ }^{\dagger}<0.1 ;{ }^{\ddagger}<0.05$.

NS: Not significant

[Corrections made here after online publication].

Copyright (C) 2008 John Wiley \& Sons, Ltd. 
asset measures of wealth, per capita expenditure was significantly inversely associated with physical and/or sexual violence in India (Panda and Agarwal, 2005) and higher self-rated poverty in Bangladesh (Ahmed, 2005) and poorer access to basic needs in Nicaragua were significantly associated with higher physical violence.

\subsection{Violence and Education}

Thirty-three sites measured the association between IPV and women's education attainment (Table 3), with a mixed range of patterns. Twenty-three sites investigated the relationship between women's education attainment and ever violence, of which nine showed a significant protective association, two a significant risk relationship and twelve no significant relationship. Of the nine sites showing a protective effect, the association between higher education and lower IPV held only for secondary or more schooling, compared to women with no education in Egypt, India and Cambodia (Kishor and Johnson, 2004) and postsecondary education in Peru (Flake, 2005). More than 8 years of schooling, compared with 0-7 years, was protective in Uganda (Karamagi et al., 2006). Significant protective effects of schooling were also documented in South Africa comparing post-school education with no post-school education (Jewkes et al., 2002), in Mexico where education was categorised in an ordinal scale (Oropesa, 1997), and in Turkey where illiterate and non-illiterate women were compared (Kocacik and Dogan, 2006). Secondary education was protective against ever experience of sexual violence in Lesotho (Brown et al., 2006). However, in Peru and Haiti (Kishor and Johnson, 2004) ever physical violence was significantly higher among women with primary schooling compared to women with no schooling.

Twenty sites investigated the association between past year violence and women's education attainment, with eleven finding a significant protective association and two a significant risk association. When compared with no education, significantly lower physical violence was found for women with secondary or more education, but not primary, in Egypt and India (Kishor and Johnson, 2004), with 5+ years, but not 1-5 years, in Bangladesh (Bates et al., 2004), with 8 or more years of schooling, but not 1-7 years, in Uganda (includes threat) (Koenig et al., 2003a) and secondary or more education in Cambodia (includes sexual violence) (Kishor and Johnson, 2004). Some education was associated with significantly lower past 4-month physical violence in Bangladesh compared with no education and there was also a significant decreasing trend associated with physical violence in rural Bangladesh (Koenig et al., 2003b; Ahmed, 2005). In Mexico, more than 10 years of education was associated with significantly lower moderate and severe physical violence compared with only 6 years of education (Rivera-Rivera et al., 2004) and in South Africa, post-school education was associated with significantly lower physical violence and physical violence and threat (Jewkes et al., 2002). Less than complete primary was associated with significantly higher physical and sexual violence and threat when compared with some secondary education in Tanzania (McCloskey et al., 2005). In two sites a higher education attainment was associated with significantly higher violence: Albania (Burazeri et al., 2005) and incomplete primary compared with no education was associated with significantly higher physical, sexual and emotional violence in Haiti (Gage, 2005). No significant association was found between education attainment and past year violence in the other seven sites.

Fifteen sites looked at the association between ever violence and men's education. Women's risk of physical violence was significantly lower when their partner had secondary or more education compared with no schooling in Egypt and India (Kishor and 


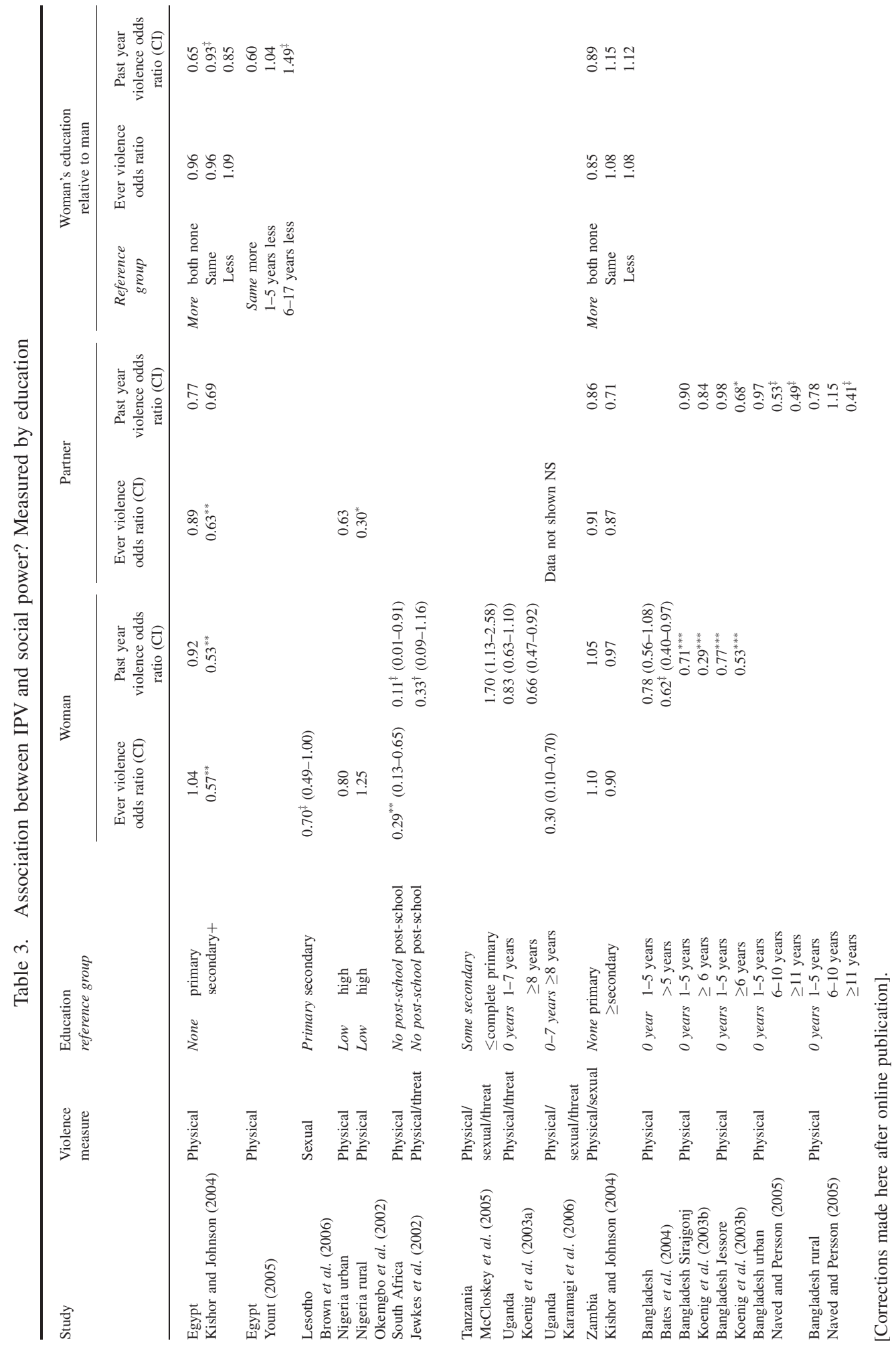




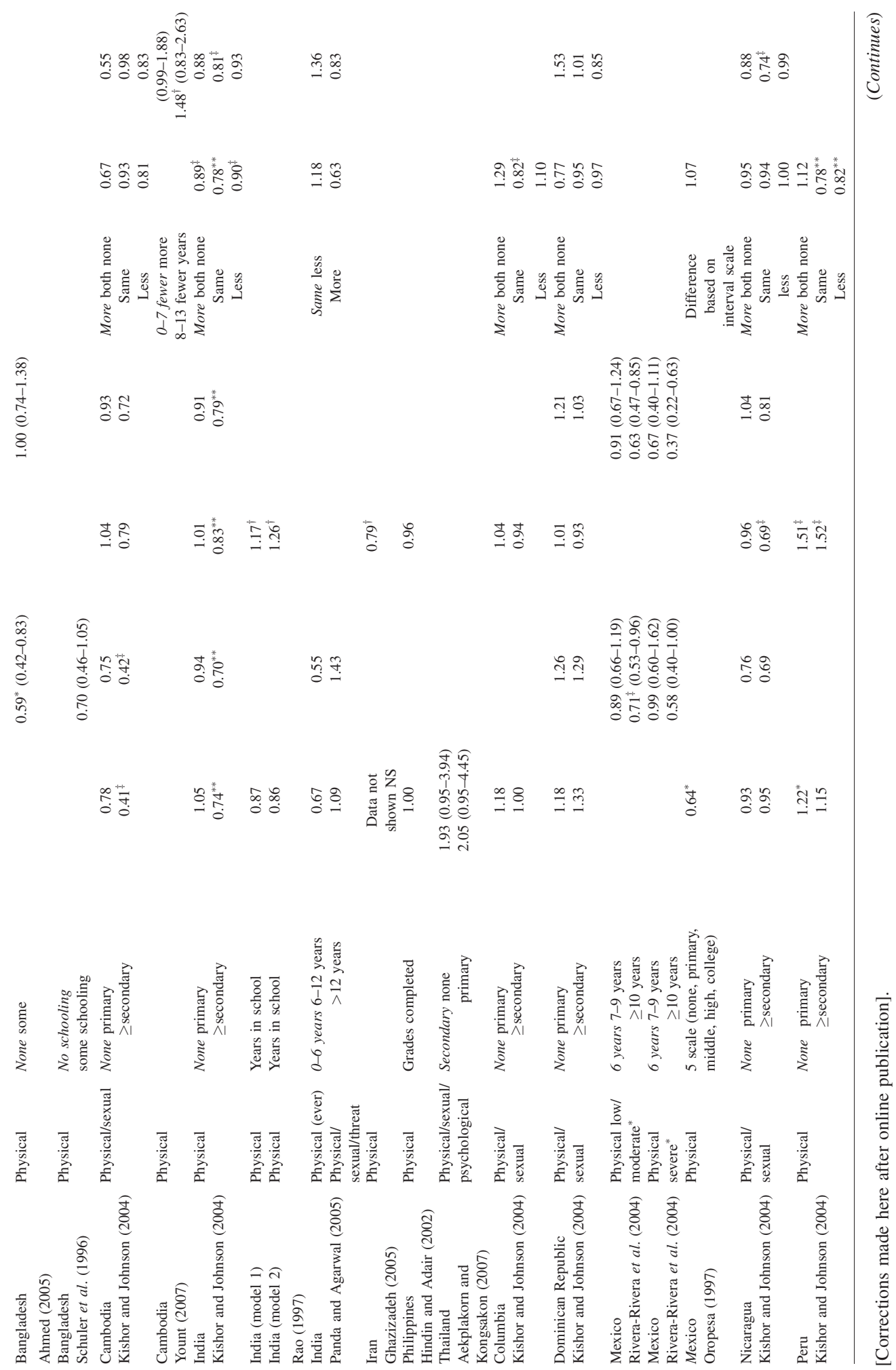




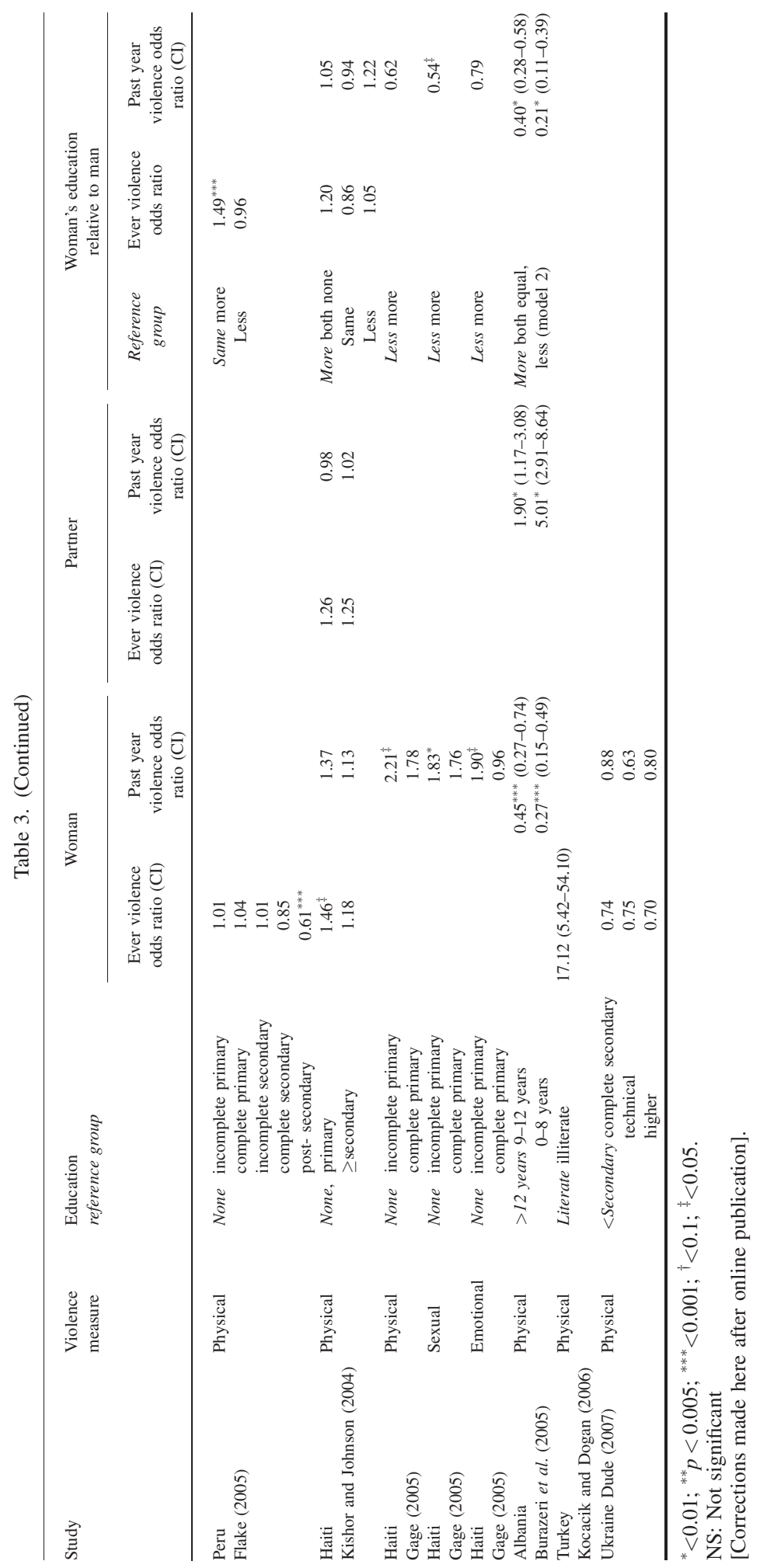


Johnson, 2004), high education compared with low education in rural Nigeria (Okemgbo et al., 2002) and higher education in Iran ((Ghazizadeh, 2005)—results not shown). Secondary or more education was also associated with lower physical and/or sexual violence in Nicaragua (Kishor and Johnson, 2004). However, higher men's education as measured by years in school was significantly associated with higher perpetration of physical violence in India and Peru (Rao, 1997; Kishor and Johnson, 2004).

Fourteen sites investigated the association between past year violence and men's education of which six found a significant inverse association and eight no association. When compared with no schooling, physical violence was significantly lower for women whose husbands had 6-10 years or 11 or more years of schooling in urban Bangladesh (Naved and Persson, 2005), 11 or more years of schooling in rural Bangladesh (Naved and Persson, 2005), 6 or more years in rural Bangladesh (Koenig et al., 2003b) and secondary or more schooling in India (Kishor and Johnson, 2004). There was a significant inverse trend relationship between physical violence and education in Albania (Burazeri et al., 2005) and 10+ years of education was associated with significantly lower moderate physical and severe physical violence in Mexico (Rivera-Rivera et al., 2004).

In Egypt, India and Peru, a woman with a higher education attainment than her partner experienced significantly higher ever physical violence compared with women who either had the same or less education than their partner (Kishor and Johnson, 2004; Flake, 2005). Ever physical and/or sexual violence was higher for women with more education than her partner in Columbia (Kishor and Johnson, 2004). No significant association between more women's education and ever violence were found in seven sites that investigated the relationship between ever violence and relative education.

Twelve sites investigated past year violence and relative education. Compared with equal education level, greater women's education was associated with significantly higher violence in Egypt, India, Nicaragua and Albania (Kishor and Johnson, 2004; Burazeri et al., 2005). Less education was associated with higher violence in Egypt and Cambodia (Yount, 2005; Yount and Carrera, 2006) and in Haiti, more women's education was significantly associated with lower sexual violence (Gage, 2005). There was no association with relative education and violence in the other five sites.

\subsection{Violence and Economic Empowerment}

When comparing being paid cash (with not working) and ever experience of violence (Table 4), physical violence was significantly lower in Egypt (Kishor and Johnson, 2004) but significantly higher in India, Peru and Iran (Kishor and Johnson, 2004; Flake, 2005), and physical and/or sexual violence was significantly higher in Columbia, Dominican Republic and Nicaragua (Kishor and Johnson, 2004). Regular employment, compared with being unemployed, was associated with significantly lower violence in India but not irregular or seasonal employment (Panda and Agarwal, 2005). In Turkey, women who were housewives had significantly lower physical and sexual violence compared with other women. There were no significant associations between physical violence and earning an income in Haiti (Kishor and Johnson, 2004) or the Philippines (Hindin and Adair, 2002), with years in employment either during the partnership or prior to union in Mexico (Oropesa, 1997), with the woman's monthly income in India (Rao, 1997) or being employed in the Ukraine (Dude, 2007). There was also no significant association between physical and/or sexual violence and earning an income in Zambia or Cambodia (Kishor and Johnson, 2004) or with being employed and sexual violence in Lesotho (Brown et al., 2006). 
The association between women's economic empowerment and past year violence was documented in 22 sites. Women earning an income was associated with significantly lower violence in one site Egypt (Kishor and Johnson, 2004). However, it was associated with higher physical violence in India (Kishor and Johnson, 2004) and rural Bangladesh (Naved and Persson, 2005), and higher physical and/or sexual violence in the Dominican Republic and Nicaragua (Kishor and Johnson, 2004). It was not significantly associated with physical violence in Haiti (Kishor and Johnson, 2004) or urban Bangladesh (Naved and Persson, 2005) or with physical and or sexual violence in Zambia or Cambodia (Kishor and Johnson, 2004). Neither regular or irregular/seasonal employment were significantly associated with physical and or sexual violence in India (Panda and Agarwal, 2005). While being in productive activities for less than 5 years was not associated with physical violence, being in productive activities for greater than 5 years was associated with significantly lower violence (Hadi, 2005), and in Albania being unemployed was associated with significantly lower violence when compared with women in white collar employment. Independent access to money was associated with significantly lower physical violence and emotional violence but not sexual violence in Haiti (Gage, 2005).

The association between being a member of a credit programme and past year physical violence was investigated in seven sites in Bangladesh which analysed cross-sectional data, of which one used a quasi-experimental design, and one site in rural South Africa, which used a cluster randomised trial design to assess the impact on past year levels of partner violence of a micro-finance and gender training intervention (The IMAGE study). The IMAGE study showed a 55 per cent reduction in women's past year experience of violence, with the change seeming to be a result both of women's economic and social empowerment (Kim et al., 2007). Two studies in rural Bangladesh showed micro-credit membership to be associated with significantly lower violence (Schuler et al., 1996). A higher association was found in one urban site (Naved and Persson, 2005) and in one rural site which measured membership of less than 2 years (Koenig et al., 2003b). No significant association was found in the other three rural sites (Koenig et al., 2003b; Ahmed, 2005; Naved and Persson, 2005).

In India, when compared with male partner responsible for household expenses, women who were responsible for household expenses had significantly higher levels of ever physical violence, whereas joint responsibility was associated with significantly lower violence (Krishnan, 2005). Higher women's economic contribution to the household was associated with significantly higher past year physical violence in one study in Bangladesh (Bates et al., 2004), but no significant association was found in two other Bangladesh sites (Schuler et al., 1996; Ahmed, 2005) or with ever physical violence in the Philippines (Hindin and Adair, 2002). Dowry payments were examined in four Bangladesh and India sites and dowry agreement, demand or payment was associated with significantly higher ever physical violence (data not shown). Higher women's autonomy index was associated with significantly higher past year physical violence in urban and rural Bangladesh (Koenig et al., 2003b), but associated with lower past year physical violence in another Bangladesh site (Hadi, 2005). Women who controlled their income experienced significantly higher levels of ever violence in India (Rao, 1997), and female dominated decision making was associated with significantly higher ever physical violence in Peru (Flake, 2005), and past year physical, emotional and sexual violence in Haiti (Gage, 2005).

Women's ownership of property was evaluated in India, and ownership of a house or a house and land were significantly associated with lower ever violence and lower past year 
Table 4. Association between IPV and women's economic empowerment

\begin{tabular}{|c|c|c|c|c|}
\hline Study & $\begin{array}{l}\text { Violence } \\
\text { measure }\end{array}$ & $\begin{array}{l}\text { Independent } \\
\text { access to resources } \\
\text { reference group }\end{array}$ & $\begin{array}{l}\text { Ever violence } \\
\text { odds ratio }(\mathrm{CI})\end{array}$ & $\begin{array}{l}\text { Past year violence } \\
\text { odds ratio }(\mathrm{CI})\end{array}$ \\
\hline $\begin{array}{l}\text { Egypt } \\
\text { Kishor and Johnson (2004) }\end{array}$ & Physical & $\begin{array}{ll}\text { Not working, } & \text { working paid cash } \\
\text { working no pay }\end{array}$ & $\begin{array}{l}0.78^{\ddagger} \\
1.79^{* *}\end{array}$ & $\begin{array}{l}0.62^{*} \\
1.76^{* *}\end{array}$ \\
\hline Egypt & Physical & Never worked for cash, worked for cash & & 0.95 \\
\hline Yount (2005) & & $\begin{array}{l}\text { Paid less of marital expenses, } \\
\text { paid same/more of marital expenses }\end{array}$ & & 0.91 \\
\hline $\begin{array}{l}\text { Lesotho } \\
\text { Brown et al. (2006) }\end{array}$ & Sexual & Unemployed, employed & $0.85(0.59-1.22)$ & \\
\hline $\begin{array}{l}\text { South Africa } \\
\text { Pronyk et al. (2006) }\end{array}$ & $\begin{array}{l}\text { Physical/ } \\
\text { sexual }\end{array}$ & Intervention, comparison & & $0.45(0.23-0.91)$ \\
\hline Zambia & Physical/ sexual & Not working, working paid cash & 1.11 & 0.96 \\
\hline Kishor and Johnson (2004) & & $\begin{array}{l}\text { working paid in kind } \\
\text { working no pay }\end{array}$ & $\begin{array}{l}0.84 \\
1.06\end{array}$ & $\begin{array}{l}0.94 \\
1.08\end{array}$ \\
\hline $\begin{array}{l}\text { Bangladesh urban } \\
\text { Naved and Persson (2005) }\end{array}$ & Physical & $\begin{array}{l}\text { Not earning income, earns income } \\
\text { Non-member of credit group, } \\
\text { member of credit group }\end{array}$ & & 1.08 \\
\hline $\begin{array}{l}\text { Bangladesh rural } \\
\text { Naved and Persson (2005) }\end{array}$ & Physical & $\begin{array}{l}\text { Not earning income, earns income } \\
\text { Non-member of credit group, } \\
\text { member of credit group }\end{array}$ & & $\begin{array}{l}1.73^{\ddagger} \\
1.08\end{array}$ \\
\hline $\begin{array}{l}\text { Bangladesh Sirajgonj } \\
\text { Koenig et al. (2003b) }\end{array}$ & Physical & $\begin{array}{l}\text { Non-member of credit group, } \\
\text { member of credit group }<2 \text { years, } \\
\text { member of credit group }>2 \text { years } \\
\text { Women's autonomy index }\end{array}$ & & $\begin{array}{c}1.26 \ddagger \\
1.01 \\
1.57^{* * *}\end{array}$ \\
\hline $\begin{array}{l}\text { Banglades Jessore } \\
\text { Koenig et al. (2003b) }\end{array}$ & Physical & $\begin{array}{l}\text { Non-member of credit group, } \\
\text { member of credit group }<2 \text { years, } \\
\text { member of credit group }>2 \text { years } \\
\text { Women's autonomy index }\end{array}$ & & $\begin{array}{c}0.89 \\
0.74 \\
0.88^{\dagger}\end{array}$ \\
\hline $\begin{array}{l}\text { Bangladesh } \\
\text { Bates et al. (2004) }\end{array}$ & Physical & $\begin{array}{l}\text { Non-member of credit group, } \\
\text { member of credit group } \\
\text { No/nominal contribution to household, } \\
\text { more than nominal }\end{array}$ & & $\begin{array}{l}0.75^{\ddagger}(0.56-1.00) \\
1.79^{*}(1.26-2.54)\end{array}$ \\
\hline $\begin{array}{l}\text { Bangladesh } \\
\text { Ahmed (2005) }\end{array}$ & $\begin{array}{l}\text { Physical } \\
\text { (past } 4 \text { months) }\end{array}$ & $\begin{array}{l}\text { Eligible non-member of credit group, } \\
\text { passive member, } \\
\text { active member of credit group, } \\
\text { skilled member of credit group } \\
\text { Contribution to household income }\end{array}$ & & $\begin{array}{l}1.36(0.79-2.36) \\
1.47(0.93-2.33) \\
0.64(0.25-1.66) \\
1.86(0.98-3.53)\end{array}$ \\
\hline $\begin{array}{l}\text { Bangladesh } \\
\text { Schuler et al. (1996) }\end{array}$ & Physical & $\begin{array}{l}\text { No credit in village, } \text { GB member, } \\
\text { BRAC member, } \\
\text { non-member in } \\
\text { village with } \\
\text { credit group }\end{array}$ & & $\begin{array}{l}0.30(0.18-0.51) \\
0.44(0.28-0.70) \\
0.66(0.45-0.96)\end{array}$ \\
\hline & & $\begin{array}{l}\text { Little or no contribution to family support, } \\
\text { substantial contribution }\end{array}$ & & $0.93(0.65-1.33)$ \\
\hline $\begin{array}{l}\text { Bangladesh) } \\
\text { Hadi (2005 }\end{array}$ & Physical & $\begin{array}{l}\text { Domestic, productive activities }<5 \text { years, } \\
\text { productive activities }>5 \text { years } \\
\text { Women's position index }\end{array}$ & & $\begin{array}{l}0.78 \\
0.33^{*} \\
0.56^{\ddagger}\end{array}$ \\
\hline $\begin{array}{l}\text { Cambodia } \\
\text { Kishor and Johnson (2004) }\end{array}$ & Physical/sexual & $\begin{array}{ll}\text { Not working, } & \text { working paid cash } \\
& \text { working paid in kind } \\
& \text { working no pay }\end{array}$ & $\begin{array}{l}1.01 \\
0.71 \\
1.07\end{array}$ & $\begin{array}{l}0.96 \\
0.73 \\
1.14\end{array}$ \\
\hline $\begin{array}{l}\text { India } \\
\text { Kishor and Johnson (2004) }\end{array}$ & Physical & $\begin{array}{ll}\text { Not working, } & \text { working paid cash } \\
\text { working no pay }\end{array}$ & $\begin{array}{l}1.57^{* *} \\
1.25^{* *}\end{array}$ & $\begin{array}{l}1.40^{* *} \\
1.09^{*}\end{array}$ \\
\hline $\begin{array}{l}\text { India } \\
\text { Krishnan (2005) }\end{array}$ & Physical & $\begin{array}{l}\text { Does not earn income, } \\
\text { woman controls her income, } \\
\text { woman gives income to spouse }\end{array}$ & $\begin{array}{l}2.66(1.38-5.13) \\
1.46(0.85-2.51)\end{array}$ & \\
\hline $\begin{array}{l}\text { India } \\
\text { Krishnan (2005) }\end{array}$ & Physical & $\begin{array}{l}\text { Spouse responsible for household expenses, } \\
\text { woman responsible } \\
\text { both responsible for household expenses }\end{array}$ & $\begin{array}{l}2.01(1.09-3.70) \\
0.46(0.23-0.89)\end{array}$ & \\
\hline $\begin{array}{l}\text { India } \\
\text { Rao (1997) }\end{array}$ & Physical & Woman's monthly income & $1.00^{* * * *}$ & \\
\hline India & Physical (ever) & Unemployed regular work & $0.41^{\ddagger}$ & 0.63 \\
\hline Panda and Agarwal (2005) & $\begin{array}{l}\text { Physical/sexual/ } \\
\text { threat }\end{array}$ & $\begin{aligned} \text { Seasonal/irregular work } \\
\text { Ownership property none, land only } \\
\text { house only } \\
\text { house and land }\end{aligned}$ & $\begin{array}{l}0.76 \\
0.13^{*} \\
0.09^{*} \\
0.05^{*}\end{array}$ & $\begin{array}{c}0.55 \\
0.39 \\
0.15^{*} \\
0.05^{*}\end{array}$ \\
\hline $\begin{array}{l}\text { Iran } \\
\text { Ghazizadeh (2005) }\end{array}$ & Physical & Housewife, employed & $1.80^{\dagger}$ & \\
\hline $\begin{array}{l}\text { Philippines } \\
\text { Hindin and Adair (2002) }\end{array}$ & Physical & $\begin{array}{l}\text { Does not work for pay, works for pay } \\
\text { No one dominates decision making; } \\
\text { woman dominates decision, } \\
\text { partner dominates decision making } \\
\text { Woman does not earn }>50 \% \\
\text { of household income, does }\end{array}$ & $\begin{array}{c}3.82^{* * *} \\
2.72^{*} \\
1.24\end{array}$ & \\
\hline
\end{tabular}

[Corrections made here after online publication].

(Continues) 
Table 4. (Continued)

\begin{tabular}{|c|c|c|c|c|}
\hline Study & $\begin{array}{l}\text { Violence } \\
\text { measure }\end{array}$ & $\begin{array}{l}\text { Independent } \\
\text { access to resources } \\
\text { reference group }\end{array}$ & $\begin{array}{l}\text { Ever violence } \\
\text { odds ratio }(\mathrm{CI})\end{array}$ & $\begin{array}{l}\text { Past year violence } \\
\text { odds ratio }(\mathrm{CI})\end{array}$ \\
\hline $\begin{array}{l}\text { Thailand } \\
\text { Aekplakorn and } \\
\text { Kongsakon (2005) }\end{array}$ & $\begin{array}{l}\text { Physical/sexual/ } \\
\text { psychological }\end{array}$ & Adequate income for expenses Yes No & $2.00(1.22-3.27)$ & \\
\hline $\begin{array}{l}\text { Columbia } \\
\text { Kishor and Johnson (2004) }\end{array}$ & Physical/sexual & $\begin{array}{ll}\text { Not working } & \text { working paid cash } \\
& \text { working paid in kind } \\
& \text { working no pay }\end{array}$ & $\begin{array}{l}1.44^{* *} \\
1.32 \\
1.55^{* *}\end{array}$ & \\
\hline $\begin{array}{l}\text { Dominican Republic } \\
\text { Kishor and Johnson (2004) }\end{array}$ & Physical/sexual & $\begin{array}{ll}\text { Not working } & \text { working paid cash } \\
& \text { working paid in kind } \\
& \text { working no pay }\end{array}$ & $\begin{array}{l}1.37^{* *} \\
1.49 \\
0.74\end{array}$ & $\begin{array}{c}1.41^{* *} \\
1.54 \\
0.73\end{array}$ \\
\hline $\begin{array}{l}\text { Mexico } \\
\text { Oropesa (1997) } \\
\text { Mexico } \\
\text { Oropesa (1997) }\end{array}$ & $\begin{array}{l}\text { Physical } \\
\text { Physical } \\
\text { Physical }\end{array}$ & $\begin{array}{l}\text { Years in employment in partnership, } \\
\text { Years in employment prior to union } \\
\text { Husband bread winner, neither employed, } \\
\text { wife/dual earner }\end{array}$ & $\begin{array}{l}1.02 \\
0.99 \\
1.53^{\ddagger} \\
0.80\end{array}$ & \\
\hline $\begin{array}{l}\text { Nicaragua } \\
\text { Kishor and Johnson (2004) } \\
\text { Peru } \\
\text { Kishor and Johnson (2004) }\end{array}$ & Physical/sexual & $\begin{array}{ll}\text { Not working } & \text { working paid cash } \\
& \text { working no pay } \\
\text { Not working } & \text { working paid cash } \\
& \text { working paid in kind } \\
& \text { working no pay }\end{array}$ & $\begin{array}{c}1.41^{* *} \\
1.17 \\
1.32^{* *} \\
1.17 \\
1.16^{*}\end{array}$ & $\begin{array}{c}1.28^{*} \\
1.06\end{array}$ \\
\hline $\begin{array}{l}\text { Peru } \\
\text { Flake (2005) }\end{array}$ & Physical & $\begin{array}{l}\text { Unemployed, employed in agriculture, } \\
\text { service, } \\
\text { professional } \\
\text { Egalitarian decision making, } \\
\text { divided decision making, } \\
\text { female dominated decision making, } \\
\text { male dominated decision making }\end{array}$ & $\begin{array}{c}1.17^{*} \\
1.47^{* * *} \\
1.33^{* * *} \\
1.20^{* * *} \\
1.32^{* * *} \\
1.08\end{array}$ & \\
\hline $\begin{array}{l}\text { Haiti } \\
\text { Kishor and Johnson (2004) }\end{array}$ & Physical & $\begin{array}{ll}\text { Not working } & \text { working paid cash } \\
& \text { working paid in kind } \\
& \text { working no pay }\end{array}$ & $\begin{array}{l}1.10 \\
0.81 \\
0.28\end{array}$ & $\begin{array}{l}1.11 \\
1.01 \\
0.34\end{array}$ \\
\hline $\begin{array}{l}\text { Haiti } \\
\text { Gage (2005) }\end{array}$ & Physical & $\begin{array}{l}\text { No independent access to money, } \\
\text { independent access to money } \\
\text { Joint household decision making, } \\
\text { woman dominates purchases, } \\
\text { man dominates household purchases } \\
\text { others say on household purchase }\end{array}$ & & $\begin{array}{c}0.56^{\ddagger} \\
1.68^{*} \\
1.51 \\
1.13\end{array}$ \\
\hline $\begin{array}{l}\text { Haiti } \\
\text { Gage (2005) }\end{array}$ & Sexual & $\begin{array}{l}\text { No independent access to money, } \\
\text { independent access to money } \\
\text { Joint household decision making, } \\
\text { woman dominates purchases, } \\
\text { man dominates household purchases } \\
\text { others say on household purchase }\end{array}$ & & $\begin{array}{c}0.90 \\
1.66^{\ddagger} \\
2.51^{\ddagger} \\
1.20\end{array}$ \\
\hline $\begin{array}{l}\text { Haiti } \\
\text { Gage (2005) }\end{array}$ & Emotional & $\begin{array}{l}\text { No independent access to money, } \\
\text { independent access to money } \\
\text { Joint household decision making, } \\
\text { woman dominates purchases, } \\
\text { man dominates household purchases } \\
\text { others say on household purchase }\end{array}$ & & $\begin{array}{c}0.52^{*} \\
2.67^{* * *} \\
2.64 \\
1.34\end{array}$ \\
\hline $\begin{array}{l}\text { Albania } \\
\text { Burazeri et al. (2005) } \\
\text { (model 1) }\end{array}$ & Physical & $\begin{array}{c}\text { White collar, } \begin{array}{l}\text { blue collar, } \\
\text { housekeeper, } \\
\text { unemployed }\end{array}\end{array}$ & & $\begin{array}{l}0.64^{\ddagger}(0.41-1.00) \\
0.36^{\ddagger}(0.14-0.96) \\
0.25^{*}(0.10-0.63)\end{array}$ \\
\hline $\begin{array}{l}\text { Albania } \\
\text { Burazeri et al. (2005) } \\
\text { (model 2) }\end{array}$ & Physical & $\begin{aligned} & \text { White collar, } \text { blue collar, } \\
& \text { housekeeper, } \\
& \text { unemployed }\end{aligned}$ & & $\begin{array}{c}0.97(0.52-1.80) \\
0.89(0.52-1.50) \\
0.55^{* * *}(0.36-0.86)\end{array}$ \\
\hline $\begin{array}{l}\text { Turkey } \\
\text { Kocacik and Dogan (2006) }\end{array}$ & $\begin{array}{l}\text { Physical } \\
\text { Sexual }\end{array}$ & Not stated, housewife & $\begin{array}{l}0.17(0.06-0.52) \\
0.17(0.04-0.81)\end{array}$ & \\
\hline $\begin{array}{l}\text { Ukraine } \\
\text { Dude (2007) }\end{array}$ & Physical & Not employed currently employed & 1.04 & 1.30 \\
\hline
\end{tabular}

${ }^{*}<0.01 ;{ }^{* *} p<0.005 ;{ }^{* * *}<0.001 ;{ }^{\dagger}<0.1 ;{ }^{\ddagger}<0.05$. [Corrections made here after online publication].

physical and or sexual violence. Ownership of land only, compared with no ownership of capital assets, was associated with significantly lower ever physical violence (Panda and Agarwal, 2005).

To illustrate this existing evidence about the relationship between different indicators of economic empowerment and risk of ever and past year IPV across LMICs, 1a and b summarise the number of sites where significant protective (left side bar dark shading) and indicative but not significant protective (left side bar light shading) associations were 
(A)

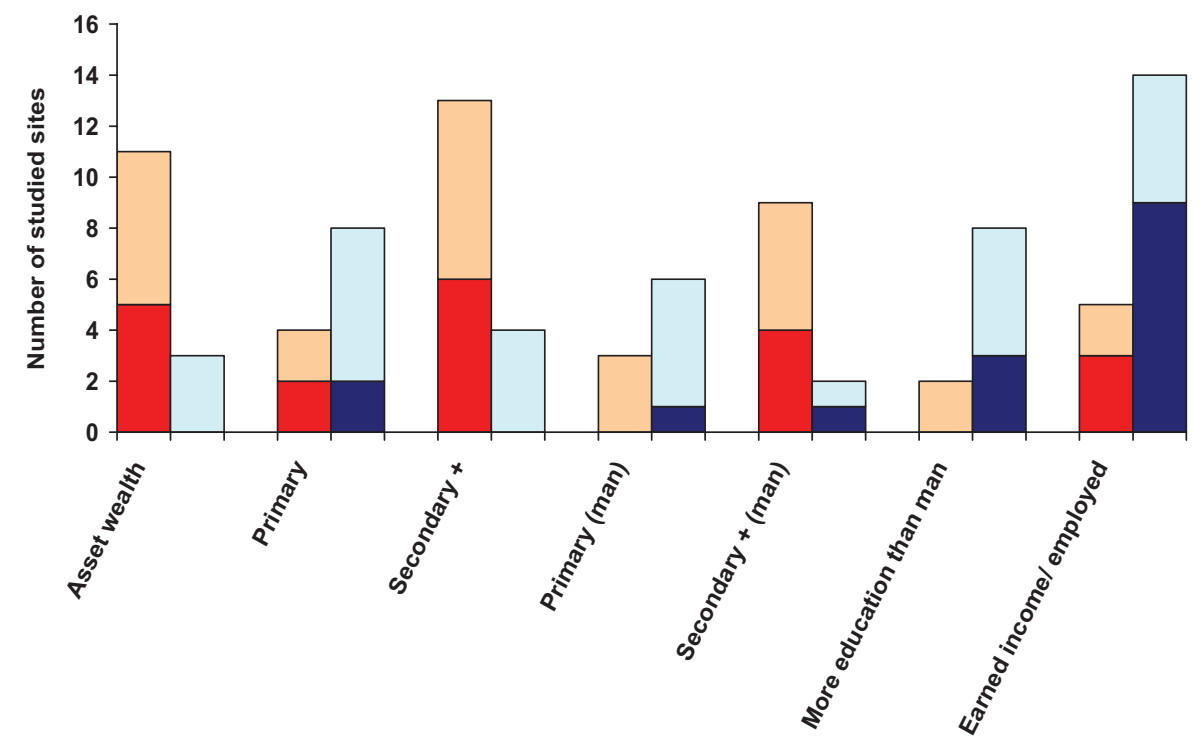

(B)

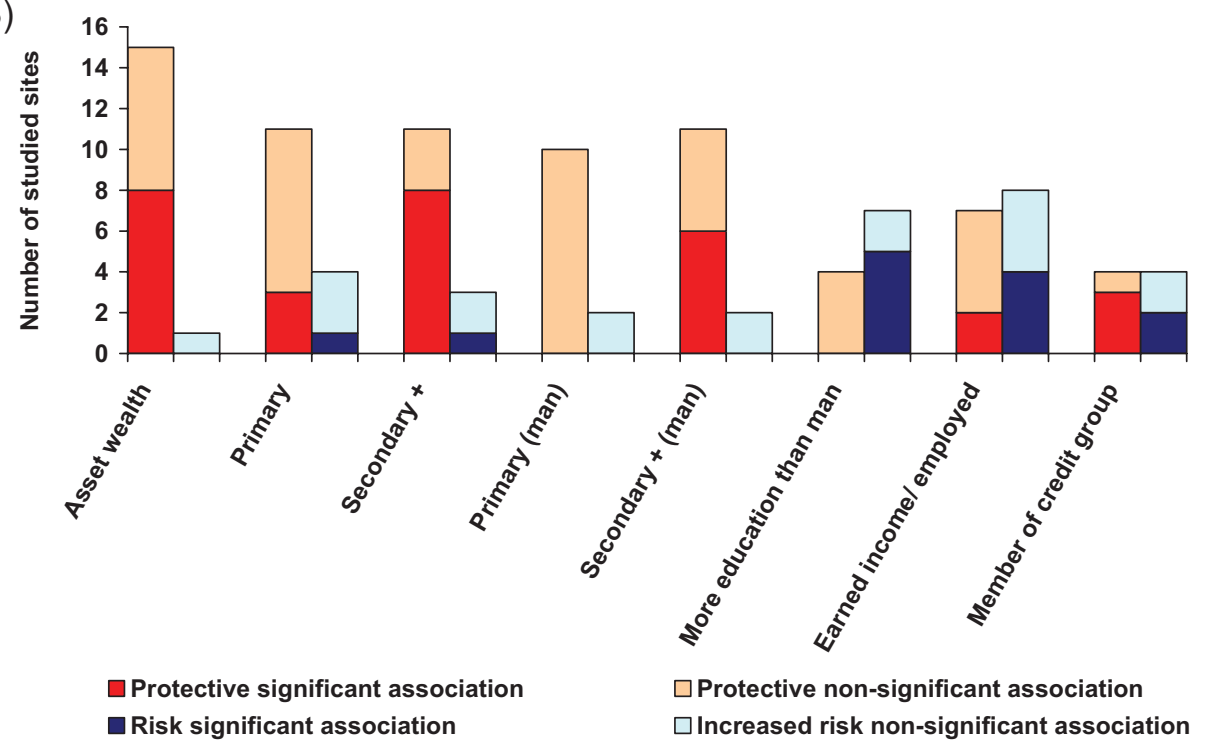

Figure 1. (a) Number of studied sites documenting either a reduced or increased risk of IPV ever violence and indicator of economic empowerment. (b) Number of studied sites documenting either a reduced or increased risk of IPV past year violence and indicator of economic empowerment. [Correction made here after initial online publication]. This figure is available in colour online at www.interscience.wiley.com/journal/jid

documented, and where significant risk and indicative but not significant risk associations were documented (right side bar dark shading and right side bar light shading, respectively).

This illustrates that there are both clear and contradictory trends. Household asset wealth seems largely protective, with several studies finding a significant or non-significant protective association with ever or past year partner violence, and only a few finding negative, but not significant, associations. Few studies appear to find women's primary 
education to be significantly protective, with an equal number of studies finding a significant negative association with ever violence, but most studies not finding any significant associations. The evidence on women's secondary education points much more to a protective effect, with several studies finding a reduced risk of ever and/or past year violence, and only one finding a significant negative impact with past year violence. The findings are similar when we look at the relationship between male education and perpetration of IPV - one study of nine finds a significant association between men's primary education and an increased risk of perpetrating violence, with most finding no association. Likewise, four studies document a protective effect of men's secondary education on the likelihood of men's perpetration of violence, with five additional studies also finding suggestive but non-significant results. Inequality in education also appear to be associated with increased risk, although there was a limited number of studies that had explore this issue. Three studies of ten find that women with a higher level of education than her partner were significantly more likely to report ever violence with a further five indicating a suggestive increased risk of violence. When considering past year violence, five studies of eleven find women with a higher level of education than her partner experience significantly higher violence, although there were four studies finding this was associated with decreased, but not significant, risk.

Evidence about the relationship between women's access to an independent source of income and risk of violence is more complex. Women's access to income was generally associated with a higher lifetime history of assault by a partner, although three studies document a significant protective association. However, considering women's risk of violence in the past year, a similar (but smaller) number of studies find a protective association as those that find an association with higher risk. Although the differences may be due to social and cultural factors, with the limited body of evidence available, it is not possible to identify any geographic patterns - the two studies finding a protective effect were Egypt and Haiti, and the four studies finding increased risk were from Bangladesh, Dominican Republic, India and Nicaragua.

\section{DISCUSSION}

The purpose of this review is to summarise the current body of quantitative evidence, largely from cross-sectional surveys, that explore the relationship between different indicators of women's economic empowerment and their risk of violence from their partner. Drawing lessons from these studies is complicated by the different sampling methods, and the measures of violence, household SES and women's access to resources used. Fear, blame and stigma may have also made some respondents reluctant to disclose IPV, potentially weakening some studies ability to identify factors significantly associated with violence. The cross-sectional nature of most studies reviewed also means that we cannot establish causality with any of the factors, and can largely only discuss the nature of associations.

Nevertheless, the findings do illustrate the degree to which socioeconomic factors are associated with violence. Higher household SES (when measured by assets) is predominantly protective, somewhat lending support to resource theories that hypothesise that poverty impacts on levels of IPV. However, there may be the potential for bias, if, for example, due to the stigma associated with IPV, higher SES groups are less likely to disclose violence (Rao, 1997; Ellsberg et al., 1999; Rivera-Rivera et al., 2004; Flake, 2005; Panda and Agarwal, 2005). In some cases also, the study design may have limited the extent to which an association could be detected quantitatively - for example, in one study in Uganda, poverty 
was not shown to be significant in the quantitative study, but arguments over money was identified as a major theme in focus group discussions (Karamagi et al., 2006).

Women's secondary education, and to some extent men's secondary education, was generally found to be protective for both ever and past year violence. There was less strong evidence of a protective effect of primary education. The reasons for this are likely to be complex - it may be that the achievement of secondary education or higher may give women greater options to not marry a man who she thinks may be violent or to leave a violent relationship, and to marry men with similar levels of education (Sen, 1999; Jewkes et al., 2002; Ahmed, 2005; Naved and Persson, 2005). Alternatively, women with higher education may also be more valued by their partner (McCloskey et al., 2005), have a stronger bargaining power within their relationship, or improved spousal communication (Hadi, 2005). Lending support to relative resource theories of violence, there was some evidence that women were at increased risk of IPV when they had a higher educational attainment than their partner.

The findings above also corroborate with studies investigating men's reported use of IPV against women in India, South Africa and Thailand that find that poverty, men's lower education attainment and lower income are associated with higher perpetration of IPV (Hoffman et al., 1994; Martin et al., 2002; Abrahams et al., 2006; Koenig et al., 2006).

The mixed findings about the relationship between women's employment and IPV risk illustrate the limitations of using simple sociological and economic theories to predict how women's access to resources may affect her risk. While marital dependency theory and economic theory would predict that increasing women's access to resources would enable her to negotiate for a more favourable situation for herself, this was not always supported by the data. In some settings, particularly where women's income may be subject to uncertainty (such as in poor rural communities where earning may be seasonal), this may not provide women with the opportunity to challenge or leave an abusive partner. In some cases also, employment was associated with increased risk, which may reflect either that men feel challenged by this, or that women with an income may be more vocal and challenge their husbands authority and experience violence (Krishnan, 2005).

While micro-finance combined with participatory gender training halved the level of IPV in South Africa (Pronyk et al., 2006), the findings associating micro-credit membership and IPV in Bangladesh were mixed. Current data suggest that financial empowerment interventions may have either a positive and negative effects on women's risk of IPV. These mixed findings may come from the potentially different effects of women's income - on the one hand women's status and economic position within the household strengthens, but on the other hand, her greater financial status may challenge the status of her partner (Schuler et al., 1998). The findings do however, need to be interpreted with caution, as most come from research in Bangladesh, which had intrinsic methodological challenges, and in particular, issues of self-selection, and what type of women may join micro-credit programmes. One study in Bangladesh found that abused women were more likely to join micro-credit programmes (Mahmud, 2000), while another found some evidence, though not significant, that women in violent partnerships were less likely to join (Steele et al., 2001). As all of the studies from Bangladesh analyse crosssectional data, and so cannot control for the timing of events, this bias may lead to misleading conclusions about the effect of micro-credit on women's risk of violence.

Despite these methodological constraints, the studies raise important questions that require further investigation. The differing results found in Bangladesh may reflect the settings in which micro-credit programmes were implemented, with increased violence 
being documented in the less progressive setting (Koenig et al., 2003b). However, other studies in Bangladesh have shown some evidence that IPV may decline with the duration of group membership (Ahmed, 2005). This suggests that the relationship seen between the past year and lifetime risk of violence, and between women who have been engaged in micro-credit for different lengths of time may be due to temporal and contextual factors, and merits further explanation. For example, it can be hypothesised that in settings where it is not common for women to work outside the home, as women initially enter into income generating activities this may lead to tensions with her partner, and so increase her risk of violence, and that women who pioneer change within a community may be at greatest risk of violence. However, this risk may decline over time, potentially as the partner starts to recognise the benefits to the household of this additional income; as women develop strategies to decrease the perceived challenge that her employment poses to her partner; or as more women start to be engaged in the formal sector; and broader social norms about the acceptability of women's employment change.

Each of these may be equally plausible. For example, some participants in the South African IMAGE intervention reported no conflict with their partner, as he was grateful for the additional household income and that there were reduced economic stresses; some chose to give their partners some of their income for alcohol or cigarettes, to reduce the potential for conflict; whilst others reported that the increased self-confidence, social support and communication skills gained from being part of a micro-finance initiative resulted in improved partner communication, so preventing any conflict escalating into violence (Kim et al., 2007).

\section{CONCLUSION}

The Millennium Development Goals challenge governments and the international community to address poverty, provide universal access to primary education, and to promote gender equality and address gender inequalities in access to secondary education. This has helped put renewed emphasis on the importance of enroling girls in school, and improving women's access to resources. Although there has been some discussion about the ways in which IPV may compromise government's ability to achieve the MDGs, the potential impact of making progress towards these goals has not been explored (WHO 2005).

The evidence from our review suggests that poverty reduction; male and female access to secondary education and reductions in inequality in education may have important protective impacts on the levels of IPV. The success of the IMAGE intervention study in halving the level of IPV in South Africa, and the positive benefits attributed to some microfinance interventions in Bangladesh illustrate the potential benefits of women's economic and social empowerment. However, our findings also show that we cannot guarantee that women's empowerment will always reduce risk. Further research is needed to better understand the ways in which women's empowerment impacts on their relationships and risk of violence, and their strategic responses to violence in different settings. The current intervention literature focusses on micro-finance, and there is a need for research on the benefits of other forms of intervention that aim to increase women's access to financial resources or empower them socially.

Finally, our review illustrates the limitations of current economic theories on violence. Current conceptual models do not explain why differing patterns of risk may be 
documented for women's access to monetary resources compared to other aspects of empowerment. Similarly, they do not explain how women's risk of IPV is influenced by broader social contexts and norms; how this risk of IPV may potentially evolve as the household financial situation improves. Conceptual models also have limitations in explaining how women's relative power or ability to resolve conflict increases as they develop social and economic empowerment skills. These limitations highlight the need to bring together economic theories, which largely focus on the household, with broader sociological findings on the ways in which gender relations at a micro-level are affected by a range of cultural, institutional and political influences acting in different spheres of men and women's lives.

\section{ACKNOWLEDGEMENTS}

We thank Julia Kim and the anonymous reviewer for their useful comments. This study was funded by: Sigrid Rausing Trust; ESRC-DFID Joint Scheme for Poverty Reduction; DFID Research Programme Consortia on Realising Rights. [Corrections made here after initial online publication].

\section{REFERENCES}

Abrahams N, Jewkes R, Laubscher R, Hoffman M. 2006. Intimate partner violence: prevalence and risk factors for men in Cape Town, South Africa. Violence and Victims 21(2): 247-264.

Aekplakorn W, Kongsakon R. 2007. Intimate partner violence among women in slum communities in Bangkok, Thailand. Singapore Medical Journal 48(8): 763-768.

Ahmed SM. 2005. Intimate partner violence against women: experiences from a woman-focused development programme in Matlab, Bangladesh. Journal of Health, Population, and Nutrition 23(1): 95-101.

Ahmed S, Koenig M, Stephenson R. 2006. Effects of domestic violence on perinatal and early childhood mortality: evidence from north India. American Journal of Public Health 96(8): 14231428.

Atkinson M, Greenstein T. 2005. For women, breadwinning can be dangerous: gendered resource theory and wife abuse. Journal of Marriage and Family 67: 1137-1148.

Bates LM, Schuler SR, Islam F, Islam K. 2004. Socioeconomic factors and processes associated with domestic violence in rural Bangladesh. International Family Planning Perspectives 30(4): 190-199.

Brown L, Thurman T, Bloem J, Kendall C. 2006. Sexual violence in Lesotho. Studies in Family Planning 37(4): 269-280.

Burazeri G, Roshi E, Jewkes R, Jordan S, Bjegovic V, Laaser U. 2005. Factors associated with spousal physical violence in Albania: cross sectional study. BMJ 331(7510): 197-201.

Campbell J. 2002. Health consequences of intimate partner violence. Lancet 359: 1331-1336.

Dobash R, Dobash R. 1979. Violence Against Wives: A Case Against Patriarchy. Free Press: New York.

Dude A. 2007. Intimate partner violence and increased lifetime risk of sexually transmitted infection among women in Ukraine. Studies in Family Planning 38(2): 89-100.

Dunkle KL, Jewkes RK, Nduna M, Levin J, Jama N, Khuzwayo N, Koss MP, Duvvury N. 2006. Perpetration of partner violence and HIV risk behaviour among young men in the rural Eastern Cape, South Africa. AIDS 20(16): 2107-2114.

Ellsberg MC, Pena R, Herrera A, Liljestrand J, Winkvist A. 1999. Wife abuse among women of childbearing age in Nicaragua. American Journal of Public Health 89(2): 241-244. 
Flake DF. 2005. Individual, family, and community risk markers for domestic violence in Peru. Violence Against Women 11(3): 353-373.

Gage AJ. 2005. Women's experience of intimate partner violence in Haiti. Social Science \& Medicine 61(2): 343-364.

Garcia-Moreno C, Jansen HA, Ellsberg M, Heise L, Watts CH. 2006. Prevalence of intimate partner violence: findings from the WHO multi-country study on women's health and domestic violence. Lancet 368(9543): 1260-1269.

Gelles RJ. 1976. Abused wives: why do they stay. Journal of Marriage and the Family 38(4): 659-668.

Ghazizadeh A. 2005. Domestic violence: a cross-sectional study in an Iranian city. Eastern Mediterranean Health Journal 11(5-6): 880-887.

Gibson-Davis C, Magnuson K, Gennetian L, Duncan G. 2005. Employment and the risk of domestic abuse among low-income women. Journal of Marriage and Family 67: 1149-1168.

Goode W. 1971. Force and violence in the family. Journal of Marriage and the Family 33: 624-636.

Hadi A. 2005. Women's productive role and marital violence in Bangladesh. Journal of Family Violence 20(3): 181-189.

Heise L. 1998. Violence against women: an integrated, ecological framework. Violence Against Women 4: 262-290.

Hindin MJ, Adair LS. 2002. Who's at risk? Factors associated with intimate partner violence in the Philippines. Social Science \& Medicine 55(8): 1385-1399.

Hoffman K, Demo D, Edwards J. 1994. Physical wife abuse in a non-western society: An integrated theoretical approach. Journal of Marriage and the Family 56(1): 131-146.

Holvoet N. 2005. Credit and women's group membership in south India: Testing models of intrahousehold allocative behaviour. Feminist Economics 11(3): 27-62.

Hornung CA, McCullough CB, Sugimoto T. 1981. Status relationships in marriage: risk factors in spouse abuse. Journal of Marriage and the Family 43: 675-692.

Jejeebhoy SJ. 1998. Associations between wife-beating and fetal and infant death: impressions from a survey in rural India. Studies in Family Planning 29(3): 300-308.

Jewkes R, Levin J, Penn-Kekana L. 2002. Risk factors for domestic violence: findings from a South African cross-sectional study. Social Science \& Medicine 55(9): 1603-1617.

Kabeer N, Mahmud S. 2004. Globalization, gender, and poverty: Bangladeshi women workers in export and local markets. Journal of International Development 16: 93-109.

Kadir M, Fikree F, Khan A, Sajan F. 2003. Do mothers-in-law matter? Family dynamics and fertility decision making in urban squatter settlements of Karachi, Pakistan. Journal of Biosocial Science 35: 545-588.

Kalmuss DS, Straus MA. 1982. Wife's marital dependency and wife abuse. Journal of Marriage and the Family 44(2): 277-286.

Karamagi CA, Tumwine JK, Tylleskar T, Heggenhouger K. 2006. Intimate partner violence against women in eastern Uganda: implications for HIV prevention. BMC Public Health 6: 284.

Kim JC, Watts CH, Hargreaves JR, Ndhlovu LX, Phetla G, Morison LA, Busza J, Porter JDH, Pronyk P. 2007. Understanding the impact of a microfinance-based intervention on women's empowerment and the reduction of intimate partner violence in South Africa. American Journal of Public Health 97(10): 1794-1802.

Kishor S, Johnson K. 2004. Profiling Domestic Violence: A Multi-Country Study. MACRO International: Calverton, MD.

Kocacik F, Dogan O. 2006. Domestic violence against women in Sivas, Turkey: survey study. Croatian Medical Journal 47(5): 742-749. 
Koenig MA, Lutalo T, Zhao F, Nalugoda F, Wabwire-Mangen F, Kiwanuka N, Wagman J, Serwadda D, Wawer M, Gray R. 2003a. Domestic violence in rural Uganda: evidence from a communitybased study. Bulletin of the World Health Organization 81(1): 53-60.

Koenig M, Ahmed S, Hossain M, Mozumder A. 2003b. Women's status and domestic violence in rural Bangladesh: individual and community-level effects. Demography 40(2): 269-288.

Koenig MA, Stephenson R, Ahmed S, Jejeebhoy SJ, Campbell J. 2006. Individual and contextual determinants of domestic violence in North India. American Journal of Public Health 96(1): 132138.

Krishnan S. 2005. Gender, caste, and economic inequalities and marital violence in rural South India. Health Care for Women International 26(1): 87-99.

Krug E, Dahlberg L, Mercy J, Zwi A, Lozano R. 2002. World Report on Violence and Health. World Health Organization: Geneva.

Macmillan R, Gartner R. 1999. When she brings home the bacon: labour-force participation and the risk of spousal violence against women. Journal of Marriage and the Family 61(4): 947958.

Mahmud S. 2000. The gender dimensions of programme participation: who joins a microcredit programme and why? Bangladesh Development Studies 26(2-3): 79-101.

Martin SL, Moracco KE, Garro J, Tsui AO, Kupper LL, Chase JL, Campbell JC. 2002. Domestic violence across generations: findings from northern India. International Journal of Epidemiology 31(3): 560-572.

McCloskey LA. 1996. Socioeconomic and coercive power within the family. Gender and Society 10(4): 449-463.

McCloskey LA, Williams C, Larsen U. 2005. Gender inequality and intimate partner violence among women in Moshi, Tanzania. International Family Planning Perspectives 31(3): 124-130.

Naved RT, Persson LA. 2005. Factors associated with spousal physical violence against women in Bangladesh. Studies in Family Planning 36(4): 289-300.

Okemgbo CN, Mimideyi AK, Odimegwu CO. 2002. Prevalence, patterns and correlates of domestic violence in selected Igbo communities of Imo State, Nigeria. African Journal of Reproductive Health 6(2): 101-114.

Oropesa RS. 1997. Development and marital power in the Mexico. Social Forces 75(4): 1291-1317.

Panda P, Agarwal B. 2005. Marital violence, human development and women's property status in India. World Development 33(5): 823-850.

Pronyk PM, Hargreaves JR, Kim JC, Morison LA, Phetla G, Watts C, Busza J, Porter JDH. 2006. Effect of a structural intervention for the prevention of intimate-partner violence and HIV in rural South Africa: a cluster randomised trial. Lancet 368(9551): 1973-1983.

Quisumbing A, Maluccio J. 2003. Resources at marriage and intrahousehold allocation: evidence from Bangladesh, Ethiopia, Indonesia, and South Africa. Oxford Bulletin of Economics and Statistics 65(3): 283-327.

Rao V. 1997. Wife-beating in rural south India: a qualitative and econometric analysis. Social Science \& Medicine 44(8): 1169-1180.

Rivera-Rivera L, Lazcano-Ponce E, Salmeron-Castro J, Salazar-Martinez E, Castro R, HernandezAvila M. 2004. Prevalence and determinants of male partner violence against Mexican women: a population-based study. Salud Pública de México 46(2): 113-122.

Roushdy R. 2004. Intrahousehold resource allocation in Egypt: does women's empowerment lead to greater investment in children? Economic Research Forum (ERF) Working Papers. Working Paper, No. 200410. Economic Research Forum: Cairo.

Schuler SR, Hashemi SM, Riley AP, Akhter S. 1996. Credit programs, patriarchy and men's violence against women in rural Bangladesh. Social Science \& Medicine 43(12): 1729-1742. 
Schuler S, Hashemi S, Badal S. 1998. Men's violence against women in rural Bangladesh: undermined or exacerbated by microcredit programmes? Development in Practice 8(2): 148-157.

Schultz T. 1990. Testing the neoclassical model of family labour supply and fertility. Journal of Human Resources 25: 599-634.

Sen P. 1999. Enhancing women's choices in responding to domestic violence in Calcutta: a comparison of employment and education. European Journal of Development Research 11(2): 65-86.

Steele F, Amin S, Naved R. 2001. Savings/credit group formation and change in contraception. Demography 38(2): 267-282.

Tauchen H, Witte A. 1995. The dynamics of domestic violence. The American Economic Review 85(2): 414-418.

Tauchen H, Witte A, Long S. 1991. Domestic violence: a nonrandom affair. International Economic Review 32(2): 491-511.

WHO. 2005. Addressing violence against women and achieving the Millenium Development Goals. Department of Gender, Women and Health, Family and Community Health, WHO: Geneva.

Yount K. 2005. Resources, family organization, and domestic violence against married women in Minya, Egypt. Journal of Marriage and the Family 67: 579596.

Yount K, Carrera J. 2006. Domestic violence against married women in Cambodia. Social Forces 85(1): 355-387. 